Adam Kalbarczyk ${ }^{1}$

Uniwersytet im. Adama Mickiewicza w Poznaniu, Polska

Wydział Teologiczny

\title{
Ksiądz Zdzisław Grzegorski — ojciec polskiej homiletyki kontekstualnej
}

Posługa przepowiadania wymaga od kaznodziei zarówno świadomości potęgi słowa Bożego i Bożego działania, jak też znajomości i rozumienia współczesności; bycia w równym stopniu teologiem i humanistą. Głoszenie słowa Bożego dokonuje się bowiem zawsze w kontekście innych przekazów religijnych i świeckich, jest zatem osadzone kontekstualnie. Kontekstualny charakter ma także wiedza o nim, czyli homiletyka, która w swoich rozważaniach powinna uwzględniać różne konteksty naukowe i kulturowe ${ }^{2}$. Przede wszystkim jednak musi ona dokonać w sobie daleko idących przeobrażeń przez konfrontację z teorią komunikacji międzyludzkiej oraz nawiązanie kontaktu i zadomowienie się w kontekstach innych dziedzin i dyscyplin wiedzy i życia ludzkiego, m.in. literatury, socjologii i antropologii. Pogląd taki wyrażał ks. Zdzisław Grzegorski (1930-2012)³, zna-

\footnotetext{
${ }^{1}$ Ksiądz Adam Kalbarczyk — kapłan archidiecezji poznańskiej, doktor habilitowany teologii, profesor nadzwyczajny homiletyki, prodziekan Wydziału Teologicznego UAM w Poznaniu; członek Poznańskiego Towarzystwa Przyjaciół Nauk; germanista, tłumacz; autor kilku książek oraz wielu artykułów z dziedziny teologii pastoralnej i teologii kaznodziejstwa; interesuje się retoryką homiletyczną, tzw. „teologią dziecięcą”, relacją między teatrem a przepowiadaniem, posługą słowa laikatu jak też historią kaznodziejstwa protestanckiego okresu ortodoksji luterańskiej; e-mail: adamkal@amu.edu.pl. ORCID: 0000-0002-3749-2497.

${ }^{2}$ Por. W. Przyczyna, Przedmowa, w: K. Müller, Homiletyka na trudne czasy, thum. M. Mijalska, Kraków 2003, s. 8.

${ }^{3}$ Ksiądz Zdzisław Grzegorz Grzegorski urodził się 13 października 1930 roku w Poznaniu. Uczęszczał do Gimnazjum św. Marii Magdaleny. W latach 1951-1957 odbył studia teologiczne w Arcybiskupim Seminarium Duchownym w Poznaniu. 30 maja 1957 roku przyjął w katedrze poznańskiej święcenia kapłańskie. Po krótkim okresie pracy duszpasterskiej w parafii odbył studia specjalistyczne w zakresie filologii polskiej na Katolickim Uniwersytecie Lubelskim (1961-1966). W 1972 roku uzyskał stopień doktora nauk humanistycznych na Uniwersytecie im. Adama Mickiewicza w Poznaniu. Zainteresowania naukowe kontynuował poprzez indywidualne studia komuni-
} 
ny poznański homileta, wykładowca homiletyki i wieloletni redaktor naczelny najstarszego polskiego periodyku homiletycznego „Biblioteka Kaznodziejska”. W swoich pracach rozwinął on zręby homiletyki zorientowanej kontekstualnie, traktującej kazanie jako akt komunikacji słowa Bożego. Uważany jest za głównego przedstawiciela czy wręcz ojca polskiej homiletyki kontekstualnej.

Niniejszy artykuł ma na celu przypomnienie i przybliżenie znaczącego wkładu tego poznańskiego teologa we współczesną refleksję nad kaznodziejstwem. Dokona się to przez omówienie najpierw dorobku publikacyjnego ks. Grzegorskiego, następnie założeń jego homiletyki kontekstualnej, na końcu zaś jego zasług w tworzeniu „Biblioteki Kaznodziejskiej”.

\section{Dorobek publikacyjny}

Ksiądz Zdzisław Grzegorski pozostawił po sobie liczne publikacje. Bibliografia prac drukowanych księdza profesora, zestawiona w układzie chronologicznym od roku 1946 po rok 2001, liczy łącznie 263 pozycje $e^{4}$. Nie uwzględniono w tym wykazie zamieszczanego systematycznie w „Bibliotece Kaznodziejskiej” od tomu 114 z 1985 roku słowa od redaktora naczelnego pt. W tym miesiacu... Ogólnie jednak można mieć wątpliwości, czy bibliografia ta rzeczywiście obejmuje wszystkie publikacje księdza profesora, tym bardziej że — jak dziś wiadomo - pisał często pod różnymi pseudonimami. Po roku 2001 ukazało się wiele następnych tekstów ks. Grzegorskiego, ale artykułów naukowych już tylko kilka.

We wszystkich swoich pracach autor podejmuje różnorodną tematykę, od opowiadań dla dzieci i młodzieży, przez studia nad teatrem religijnym, literaturą i środkami społecznego przekazu, aż po artykuły i książki z dziedziny homiletyki i komunikacji słowa Bożego.

Od 1946 do 1969 roku mamy w opublikowanym wykazie bibliograficznym do czynienia wyłącznie z krótkimi, często jednostronicowymi, acz wartościowymi

\footnotetext{
kacji międzyludzkiej w Stanach Zjednoczonych pod kierunkiem Franka E.X. Dance'a, profesora komunikacji na Uniwersytecie w Denver, jak też pobyt w Institute of Advanced Pastoral Studies w Bloomfield Hills w Michigan. Od 1967 do 1999 roku wykładał homiletykę na Papieskim Wydziale Teologicznym oraz Wydziale Teologicznym UAM w Poznaniu, a w latach 1969-1976 także w Akademii Teologii Katolickiej w Warszawie jako adiunkt przy katedrze homiletyki. Od 1985 do 2004 roku był redaktorem naczelnym wydawanego w Poznaniu najstarszego polskiego periodyku homiletycznego „Biblioteka Kaznodziejska”. Przez wiele kadencji był członkiem Komisji Episkopatu Polski ds. Środków Społecznego Przekazu. Zmarł 15 października 2012 roku w Poznaniu. Więcej na temat życia ks. Grzegorskiego w jego niebanalnej, napisanej pięknym językiem, liczącej prawie 80 stronic autobiografii. Zob. Z. Grzegorski, Autobiografia, „Poznańskie Studia Teologiczne” 10 (2001), s. 415-494. Tom ten zadedykowano ks. Grzegorskiemu z okazji jego 70 urodzin.

${ }^{4}$ Zob. Bibliografia prac drukowanych księdza profesora Zdzisława Grzegorskiego, opr. M. Przepióra, „Poznańskie Studia Teologiczne” 10 (2001), s. 495-506.
} 
zarówno pod względem merytorycznym, jak i literackim, tekstami o charakterze popularnoteologicznym, praktycznym i rozważaniowym, publikowanymi głównie w „Gościu Niedzielnym” i „Przewodniku Katolickim”. Wszystkie one — nawet te najwcześniejsze - ujawniają nieprzeciętny talent pisarski ks. Grzegorskiego.

W 1970 roku publikuje on swoją pierwszą pracę naukową: liczący 29 stron artykuł na temat posługi słowa w schemacie teorii informacji, opublikowany w periodyku „Studia Theologica Varsaviensia”. W sumie — do 2005 roku ks. Grzegorski wydał drukiem 35 prac naukowych, w tym: 12 artykułów w monografiach zbiorowych, 22 artykuły w czasopismach naukowych, takich jak „Studia Theologica Varsaviensia”, „Katecheta”, „Roczniki Humanistyczne”, „The Clergy Review”, „Ateneum Kapłańskie”, „Poznańskie Studia Teologiczne” i „Teologia Praktyczna”, oraz jedną, liczącą 251 stron, książkę naukową zatytułowaną Homiletyka kontekstualna, stanowiącą nie podręcznik homiletyki kontekstualnej - jak by to sugerował jej tytuł - lecz zbiór tekstowo autonomicznych względem siebie artykułów, opublikowanych wcześniej osobno w różnych periodykach naukowych lub dziełach zbiorowych, wydany w serii Biblioteki Pomocy Naukowych Wydziału Teologicznego UAM w Poznaniu w 1999 roku.

Wśród wyliczonych tu prac naukowych znajdują się dwie w językach obcych: jedna po angielsku z 1973 roku — na temat kaznodziejstwa w Polsce, w wydawanym w Londynie międzynarodowym piśmie akademickim „The Clergy Review"5; druga po francusku — o historii teatru religijnego w latach 1939-1945 w pracy zbiorowej pod redakcją Ireny Sławińskiej i Stefana Sawickiego na temat sacrum we współczesnej literaturze polskiej, wydanej w Lublinie w 1978 roku$^{6}$.

Tytuły prac naukowych ks. Grzegorskiego odzwierciedlają szerokie spektrum jego humanistycznych i teologicznych zainteresowań oraz obszarów badań. Należą do nich przede wszystkim poszukiwania homiletyczne w zakresie nowej, tzn. opartej na nowych źródłach refleksji homiletycznej; tworzenia nowej teorii, koncepcji przekazu słowa Bożego; kontekstualnego charakteru współczesnej homiletyki; literatury, a zwłaszcza tzw. antropologii literackiej jako źródła refleksji nad kaznodziejstwem i tworzywa kazań; funkcji kaznodziei w komunikacyjnym modelu przepowiadania; możliwości homiletycznej adaptacji amerykańskiej komunikacji retorycznej; homiletyki akademickiej w USA; homiletyki żydowskiej; dydaktyki homiletyki; formacji homiletycznej alumnów seminariów duchownych; problematyki wartościowania kazań; umiejętności proklamacji słowa Bożego. Interesowały go zagadnienia środków społecznego przekazu i kultury audiowizualnej, które podejmował w artykułach poświęconych katechezie i wy-

5 Zob. Z. Grzegorski, Preaching in Poland, „The Clergy Review” 2 (1973), s. 103-114.

${ }^{6}$ Zob. tenże, Du côte de l'espoir. L'histoire du théâtre religieux pendant la guerre de 1939 1945, w: La littérature contemporaine Polonaise et le Sacré, 5, sous la direction: I. Sławińska, S. Sawicki, Lublin 1978, s. 59-92. 
chowaniu religijnemu, jak np. pedagogia masowego przekazu w obrębie katechezy; audiowizja i problemy współczesnej katechezy zintegrowanej; formacja do dialogu w rodzinie wobec wpływu masowego przekazu; współkształtowanie środków społecznego przekazu przez katolików. Zajmował się literaturą i teatrem religijnym, proponując w swoich artykułach wykorzystanie utworów literackich w katechezie czy inscenizację religijną jako środek wychowania w wierze.

Język tych prac jest czasami trudny, a styl niemalże eseistyczny, co jednak nie ujmuje im naukowego charakteru. Liczne odniesienia do najświeższej wówczas literatury obcojęzycznej z obszaru teorii komunikacji i homiletyki, głównie amerykańskiej, opatrzone starannym aparatem krytycznym, świadczą nie tylko o naukowej świeżości i wartości tych tekstów, lecz także o klimacie intelektualnej uczciwości, w którym powstały.

Przyglądając się bibliografii ks. Grzegorskiego, nietrudno zauważyć, że większość jego prac naukowych powstała i została opublikowana w latach siedemdziesiątych i na początku lat osiemdziesiątych minionego wieku. Wiąże się to niewątpliwie $\mathrm{z}$ jego zaangażowaniem $\mathrm{w}$ tamtym czasie jako wykładowcy homiletyki na Papieskim Wydziale Teologicznym w Poznaniu, jego pracą naukową na Akademii Teologii Katolickiej w Warszawie, przyjaźnią i współpracą z ks. Leszkiem Kucem (1927-1986)7 , zajmującym się teologią komunikacji, jak też z dwoma pobytami studyjnymi w Stanach Zjednoczonych ${ }^{8}$. Był to czas, gdy kształtowało się jego pole zainteresowań: koncepcja interdyscyplinarnego czy — jak wolał mówić — kontekstualnego pojmowania homiletyki. Później — w latach dziewięćdziesiątych XX wieku i początkach XXI wieku — ukazują się drukiem niestety już tylko nieliczne jego prace naukowe.

\section{Zręby homiletyki kontekstualnej}

Ostatni artykuł ks. Grzegorskiego, zatytułowany Homiletyka kontekstualna. Przyszłość - przeszłość, ukazał się w 2005 roku9. Autor — jak wynika ze wstę$\mathrm{pu}$ - potraktował tę wypowiedź jako rodzaj „testamentu” i podsumowania nurtu zapoczątkowanego w 1969 roku próbą włączenia teorii komunikacji w naukową refleksję nad kaznodziejstwem i rozwiniętego w 1974 roku w artykule zatytułowanym $O$ kontekstualny charakter współczesnej homilety $k^{10}$, będącym swoistym „manifestem” homiletyki kontekstualnej. „Homiletyka — pisał w nim —

\footnotetext{
7 Zob. tenże, Autobiografia, s. 481-482.

${ }^{8}$ Zob. tamże, s. 461-466, 467-471.

9 Zob. tenże, Homiletyka kontekstualna. Przyszłość — przeszłość, „Poznańskie Studia Teologiczne" 18 (2005), s. 125-133.

${ }^{10}$ Zob. tenże, O kontekstualny charakter współczesnej homiletyki, „Studia Theologica Varsaviensia" 1 (1974), s. 79-118.
} 
musi być zawsze współczesna, jej postulaty winny być aktualne, żywe, muszą się sprawdzać podczas sprawowania posługi słowa. Drogą do tego jest sensowny dialog kościelnej tradycji komunikacji słowa z normami współczesnymi" ${ }^{11}$. Swoją „nową” homiletykę oparł na amerykańskiej teorii przekazu religijnego, homiletycznego, będącego złożonym procesem interakcji o zasięgu personalnym i społecznym, a nie - jak to czyniono dotychczas w obrębie retoryki klasycznej — na samym kazaniu jako tekście wypowiedzi ${ }^{12}$.

W swoim obszernym Wprowadzeniu do teorii przekazu homiletycznego z 1973 roku $^{13}$ ks. Grzegorski podjął myśl Herberta Marshalla McLuhana (19111980), kanadyjskiego teoretyka komunikacji, że „sam sposób przekazu jest przekazem", a zatem

całość teorii przekazu zmierza do inspirowania myślenia kategoriami słowa Bożego i kategoriami człowieka słuchającego, a więc kategoriami komunikacji i porozumiewania. Między [...] postulatywnością dawnej homiletyki a deskryptywnością współczesnej wiedzy o komunikacji winna znaleźć swoje miejsce nowa homiletyka, którą należy rewaloryzować i przekształcić tak przez refleksję nad słowem Bożym, jak i słowem człowieka do człowieka ${ }^{14}$.

Nowa homiletyka powinna zatem patrzeć na przekaz słowa Bożego kontekstualnie, czyli od strony kształtujących go sytuacji. Kaznodziei przypada w tym bogatym zespole interakcji rola słuchającego człowieka, słuchającego kogoś drugiego - w dynamicznym akcie intelektualnym, zawsze uwzględniającego w kazaniu wielostronny kontekst życia, sferę doświadczania świata przez współczesnego człowieka, a więc wszystkich zjawisk, które tak a nie inaczej kształtują adresata, a który przez kaznodzieję ma zostać sprowokowany do kreacyjnego procesu. W tym procesie zaznacza się — jako zasadniczy parametr odbioru wolność człowieka i jego tajemnicza reakcja. Stąd przepowiadanie jest zarówno misterium Boga, jak i misterium człowieka, jest w swej głębi tajemnicą, wobec której stają wszyscy partnerzy interakcji. Dlatego nie da się zdefiniować słowa w całej pełni. Zawsze pozostanie ono dla nas

tajemnicą — misterium ludzkim, a zarazem Bożym, tak w sensie ukonstytuowania człowieka, jak i w sensie realizowania się zamierzeń łaski Bożej. Słowo jako

11 Tenże, Homiletyka kontekstualna, Biblioteka Pomocy Naukowych 13, Poznań 1999, s. 31.

12 Por. G. Kubski, O homiletyce kontekstualnej Zdzisława Grzegorskiego, „Poznańskie Studia Teologiczne" 10 (2001), s. 247-252, tu: s. 249-250.

${ }_{13}$ Zob. Z. Grzegorski, Wprowadzenie do teorii przekazu homiletycznego, w: Praktyka przepowiadania słowa Bożego. Materiaty do nauczania $w$ zakładach teologicznych, t. 2, red. L. Kuc, Warszawa 1973, s. 19-138.

14 Tamże, s. 21. 
rzeczywistość słyszana jest darem w swej naturze bliskim innemu misterium, jakim jest rozumienie i pojmowanie rzeczywistości. Bóg objawiając się człowiekowi w słowie, wkroczył w jego proces pojmowania siebie samego ${ }^{15}$.

Jak widać, kontekstualnie rozumiane jest tutaj samo słowo — jako element misterium pojmowania rzeczywistości.

Z pojęciem kontekstu dla homiletyki ks. Grzegorski łączy dwa kręgi: ,pokrewnych dyscyplin naukowych i nauki o innych środkach i metodach przekazu oraz pokrewnych wartości, cenionych przez człowieka, tworzonych przezeń, uznawanych czy gloryfikowanych, przekazywanych drugim"16. Dlatego do elementów składowych homiletyki kontekstualnej, a w niej teorii przekazu religijnego, należą: „,wiedza o środkach przekazu i prawach nimi rządzących oraz wiedza o zawartości przekazów stykających się w czasie i przestrzeni z kazaniem, wartości eksponowanych przez współczesną kulturę"17. Charakterystyczną cechą proponowanego i rozwijanego przez ks. Grzegorskiego nurtu kontekstualnego w homiletyce jest koncentracja na momencie nawiązania kontaktu, procesie przekazywania słowa i tym wszystkim, co się w tej chwili dzieje w sensie nadprzyrodzonym, jak też sytuacyjność, egzystencjalność patrzenia na moment słuchania słowa Bożego, nawiązywanie do „pobliskich kontekstów wiedzy, do kultury i problemów, które formują słuchacza i z którymi przyszedł słuchać, do których wróci”"18.

Przekaz homiletyczny jest procesem zainicjowanym przez Boga - głównego Nadawcę. „Podejmuje go i realizuje człowiek aktualnie sprawujący posługę słowa" ${ }^{19}$. Jego wypowiedź należy do jego osobistego kontekstu, jest efektem jego przemyśleń i dialogu z Bogiem. Wypowiedź ta ma być przyjęta i włączona przez odbiorcę do jego osobistego kontekstu myślowego. Proces ten przebiega zawsze w kontekście współczesności. W ten sposób kontekst czasowy, przyrodzony, spotyka się z kontekstem wiecznym, nadprzyrodzonym. Rozpoznaniu kontekstów słuchacza ma służyć sondaż kontekstów kulturowych zarówno w obrębie kultury masowej, niższej kultury, jak i kultury wyższej, literatury, teatru, tego, co człowiek mówi sam o sobie ${ }^{20}$.

Ostatnim przejawem ukierunkowania kontekstualnego homiletyki jest postulat wprowadzenia głosu i doświadczeń pokrewnych specjalistów w proces analizy wydarzenia kaznodziejskiego, albo inaczej: postulat przeprowadzenia analizy kontekstualnej kazania, jego krytycznej oceny przez grono specjalistów (teologa,

15 Tamże, s. 31; por. tenże, Homiletyka kontekstualna ..., s. 128.

16 Tenże, O kontekstualny charakter..., s. 91.

17 Tamże.

18 Tamże.

19 Tenże, Monolog czy dialog? Między pięknem a skutecznościa — ujęcie kontekstualne, „Poznańskie Studia Teologiczne" 14 (2003), s. 121-132, tu: s. 126.

${ }^{20}$ Zob. tenże, O kontekstualny charakter..., s. 101. 
biblistę, pedagoga, pastoralistę, eksperta w dziedzinie retoryki, eksperta w dziedzinie komunikacji międzyludzkiej) i przedstawicieli słuchaczy, laikatu. Analiza ta ma pomóc w znalezieniu odpowiedzi na pytanie, co rzeczywiście wydarzyło się podczas głoszenia słowa Bożego ${ }^{21}$.

Założenia homiletyki kontekstualnej ks. Grzegorski koncypował i realizował w swoich wykładach i ćwiczeniach w Poznaniu i Warszawie. Koncepcja była rozwijana w licznych sympozjach, konferencjach i związanych z nimi dyskusjach, budząc zainteresowanie także niekościelnych instytucji, co świadczy o jej inspirującej obecności ${ }^{22}$. Nurt refleksji komunikacyjnej i kontekstualnej w homiletyce popularyzowany przez ks. Grzegorskiego oraz jego apel o interdyscyplinarność i wyjście z ,homiletycznego getta” ${ }^{23}$, został odnotowany najpierw przez ks. Antoniego Lewka (1940-2010) ${ }^{24}$. Pierwszą próbę ujęcia homiletyki w kluczu kontekstualnym podjął ks. Zbigniew Adamek ${ }^{25}$. W nurcie tym plasuje się też interesujące opracowanie na temat skuteczności głoszenia słowa Bożego autorstwa o. Gerarda Siwka CSsR (1938-2015) ${ }^{26}$ i artykuł ks. Józefa Dołegi (1940-2014) o komunikacji interpersonalnej w obrębie kaznodziejstwa ${ }^{27}$. Promowane przez ks. Grzegorskiego komunikacyjne zorientowanie refleksji homiletycznej widać też w pracach o. Klemensa Jockwiga CSsR ${ }^{28}$, ks. Jana Pracza ${ }^{29}$ i o. Władysława Chaima CSsR ${ }^{30}$. Niemniej w 1997 roku ks. Grzegorski ubolewał nad tym, że „nie ma komunikacji między homiletami interesującymi się komunikacją w homiletyce" 31 .

Wartość zaproponowanej przez ks. Grzegorskiego koncepcji homiletyki kontekstualnej leży przede wszystkim w dostrzeżeniu związku między formami przekazu religijnego a innymi formami przekazu, jak też w zwróceniu uwagi na to, że skuteczność głoszenia słowa Bożego zależy w dużej mierze od właściwego zakomunikowania. Posługa słowa tworzy, według niego, swoisty kanał informacji, w którym istotną rolę odgrywa świadomość teologiczna, usposobienie głoszącego, postawa odbiorcy, kontekst bliższy i dalszy oraz język. Kazanie jest

21 Zob. tamże, s. 115-118.

22 Zob. tenże, Homiletyka kontekstualna..., s. 126.

23 Tenże, Kaznodzieja w komunikacyjnym modelu przepowiadania, w: Stuga Stowa, red. W. Przyczyna, Kraków 1997, s. 193-201, tu: s. 194.

24 Zob. A. Lewek, Współczesna odnowa kaznodziejstwa, z. 1, Warszawa 1980, s. 95, 108.

25 Zob. Z. Adamek, Homiletyka, Tarnów 1992.

26 Zob. G. Siwek, Skuteczniej przepowiadać. Elementy retoryki kaznodziejskiej, Kraków 1992.

27 Zob. J. Dołęga, Z podstawowych zagadnień komunikacji, ,Studia Teologiczne Białostocko-Drohiczyńsko-Łomżyńskie" 9 (1991), s. 305-316.

${ }_{28}$ Zob. K. Jockwig, Dydaktyka homiletyki w aspekcie nowych tendencji w kaznodziejstwie, w: W drodze na ambone, red. G. Siwek, Kraków 1991, s. 46-61.

29 Zob. J. Pracz, Kazanie jako akt komunikacji, w: Fenomen kazania, red. W. Przyczyna, Kraków 1994, s. 83-97.

30 Zob. W. Chaim, Kazanie jako komunikat, w: tamże, s. 98-135.

31 Z. Grzegorski, Kaznodzieja..., s. 194. 
aktem komunikacji międzyludzkiej, pełniącym funkcję poznawczą, impresywną (konatywną), fatyczną (kontaktową) i profetyczną (wieszczącą). Dlatego kaznodzieja powinien zawsze sprawdzać funkcjonowanie kanału komunikacyjnego przez obserwację teologiczną i postulatywną.

\section{Redagowanie „Biblioteki Kaznodziejskiej”}

Miejscem i jednocześnie zadaniem, w którym ogniskowało się całe dotychczasowe doświadczenie i przygotowanie intelektualne ks. Grzegorskiego, gdzie realizowała się kontekstualność kaznodziejstwa w praktyce, była redakcja „Biblioteki Kaznodziejskiej”. Redagowanie tego pisma przez prawie 20 lat traktował jako swoiste „duszpasterzowanie”, choć pośrednio — przez księży, którym podsuwał materiały pomocnicze - nie łatwe, lekkie i przyjemne, wyciskające łzy, gotowe do mechanicznego odczytania na ambonie, lecz prowokujące ich do przemyśleń, opracowania własnej wersji. Najważniejszą zaś innowacją wprowadzoną przez niego do tego sędziwego periodyku była coraz aktywniejsza rola osób świeckich, wchodzących w forum współpracy księży (tak rozumiał funkcjonowanie miesięcznika homiletycznego). Zaproponowane sugestie słuchacza, komentarze słuchacza zaznajomionego z tematyką homilii, którą duszpasterz ma przygotować, traktował jako „trzymanie ręki na pulsie”. Treść tych komentarzy jest — jak pisał w swojej autobiografii - kopalnią „refleksji nad stanem religijności, konkretnymi zapotrzebowaniami przykładowego polskiego katolika, brakami w wykształceniu katechetycznym”, dowodem „zwątpień i niepokojów”, rzeczą godną „oglądu i zastanowienia - nie tylko czytających numer duszpasterzy..." "32.

Ksiądz profesor Wiesław Przyczyna, znany krakowski homileta, długoletni przewodniczący Sekcji, a później Stowarzyszenia Homiletów Polskich, powiedział w wywiadzie z Katarzyną Zagórską, że kierowane przez ks. Grzegorskiego pismo „stało się nowoczesnym forum wymiany myśli, a nie tylko zbiorem gotowych pomocy kaznodziejskich”33. Redagowany przezeń miesięcznik homiletyczny „osiągną — jak powiedział ks. Bogdan Reformat, ówczesny dyrektor Drukarni i Księgarni św. Wojciecha (wydawcy pisma) — wysoki poziom edytorski i stał się wyróżniającą pozycją wśród propozycji wydawniczych kierowanych do duszpasterzy"34.

Przedstawienie dzieła ks. Zdzisława Grzegorskiego będzie niepełne bez uwzględnienia kontekstu jego życia, nieprzeciętnych uzdolnień i bogatej osobowości,

\footnotetext{
32 Z. Grzegorski, Autobiografia, s. 490.

${ }^{33}$ Zadany Dar, „Przewodnik Katolicki” 41 (2004), s. 21.

${ }^{34}$ Cyt. za: Z. Grzegorski, Homiletyka kontekstualna ..., s. 133.
} 
której podstawowym wyróżnikiem była wyjątkowa wrażliwość. To z niej zrodziło się jego dzieło. Ona też tłumaczy to wszystko, czego nie napisał.

$\mathrm{Na}$ końcu tego dzieła trzeba dostrzec wielokropek - ulubiony znak interpunkcyjny ks. Grzegorskiego. Znaczy on, że jego dzieło jest niedokończone, pozostawione nam do dalszego rozwijania i popularyzacji, ażeby w Kościele przyjęło się wreszcie kontekstualne rozumienie i praktykowanie komunikacji słowa Bożego. Jest to koniec końców zaproszenie do - jak pisał we wprowadzeniu do swojej Homiletyki kontekstualnej — czynienia homiletyki i kaznodziejstwa „żywym elementem nowej ewangelizacji, faktycznie posługa słowa we wkorzenianiu się Kościoła we współczesną kulturę"33.

\section{Zdzislaw Grzegorski — father of Polish contextual homiletics}

\section{Summary}

The article reminds and introduces the work of Zdzisław Grzegorski (1930-2012), a theologian from Poznań, a lecturer of homiletics and the editor of the "Biblioteka Kaznodziejska" (Preachers' Library), called the father of the Polish school of contextual homiletics. The contextual homiletics, which he created and popularized in numerous publications, deals with the relationship of the forms of religious messages to other forms of communication and makes the effectiveness of proclaiming the word of God relevant to communicating. The service of the word creates a peculiar channel of information, consisting of such elements as: theological awareness, disposition of the preacher, the attitude of the recipient, the closer and further context, the language. The communication act on the pulpit has various functions: cognitive, conative, phatic and prophetic. The preacher should check the functioning of the communication channel through the theological and postulative observation.

Grzegorski's concept was developed in a few national symposia and conferences. It had a significant impact on the contemporary Polish homiletic reflection. The communication and contextual orientation can be seen in several works of Polish preachers. Nevertheless, Grzegorski's work demands further development and popularization, so that the contextual understanding and practice of communicating the word of God has been adopted in the Church.

\section{Keywords}

Zdzisław Grzegorski, contextual homiletics

\section{Słowa kluczowe}

Zdzisław Grzegorski, homiletyka kontekstualna

\footnotetext{
35 Tenże, Homiletyka kontekstualna, s. 7.
} 


\section{Bibliografia}

Adamek Z., Homiletyka, Tarnów 1992.

Bibliografia prac drukowanych księdza profesora Zdzisława Grzegorskiego, opr. M. Przepióra, „Poznańskie Studia Teologiczne” 10 (2001), s. 495-506.

Chaim W., Kazanie jako komunikat, w: Fenomen kazania, red. W. Przyczyna, Kraków 1994, s. 98-135.

Dołęga J., Z podstawowych zagadnień komunikacji, „Studia Teologiczne Białostocko-Drohiczyńsko-Łomżyńskie" 9 (1991), s. 305-316.

Grzegorski Z., Autobiografia, „Poznańskie Studia Teologiczne” 10 (2001), s. 415-494.

Grzegorski Z., Du côte de l'espoir. L'histoire du théâtre religieux pendant la guerre de 1939-1945, w: La littérature contemporaine Polonaise et le Sacré, 5, sous la direction: I. Sławińska, S. Sawicki, Lublin 1978, s. 59-92.

Grzegorski Z., Homiletyka kontekstualna, (Biblioteka Pomocy Naukowych 13), Poznań 1999.

Grzegorski Z., Homiletyka kontekstualna. Przyszłość — przeszłość, „Poznańskie Studia Teologiczne" 18 (2005), s. 125-133.

Grzegorski Z., Kaznodzieja w komunikacyjnym modelu przepowiadania, w: Stuga Stowa, red. W. Przyczyna, Kraków 1997, s. 193-201.

Grzegorski Z., Monolog czy dialog? Między pięknem a skutecznościa - ujęcie kontekstualne, „Poznańskie Studia Teologiczne” 14 (2003), s. 121-132.

Grzegorski Z., O kontekstualny charakter wspótczesnej homiletyki, „Studia Theologica Varsaviensia" 1 (1974), s. 79-118.

Grzegorski Z., Wprowadzenie do teorii przekazu homiletycznego, w: Praktyka przepowiadania słowa Bożego. Materiały do nauczania $w$ zakładach teologicznych, t. 2, red. L. Kuc, Warszawa 1973, s. 19-138.

Jockwig K., Dydaktyka homiletyki $w$ aspekcie nowych tendencji w kaznodziejstwie, w: W drodze na ambonę, red. G. Siwek, Kraków 1991, s. 46-61.

Kubski G., O homiletyce kontekstualnej Zdzisława Grzegorskiego, „Poznańskie Studia Teologiczne" 10 (2001), s. 247-252.

Lewek A., Współczesna odnowa kaznodziejstwa, z. 1, Warszawa 1980.

Müller K., Homiletyka na trudne czasy, tłum. M. Mijalska, Kraków 2003.

Pracz J., Kazanie jako akt komunikacji, w: Fenomen kazania, red. W. Przyczyna, Kraków 1994, s. 83-97.

Siwek G., Skuteczniej przepowiadać. Elementy retoryki kaznodziejskiej, Kraków 1992.

Zadany Dar, wywiad K. Zagórskiej z o. W. Przyczyną, „Przewodnik Katolicki” 41 (2004), s. 21. 